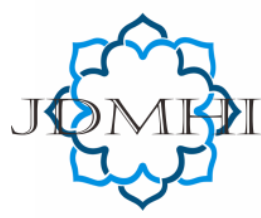

email: jdmhi@walisongo.ac.id

Journal of Digital Marketing and Halal Industry

ISSN: 2716-4810 (print) ISSN: 2716-4802 (online)

\title{
The Influence of Product Quality, Product Design, Brand Image on Realme Smartphone Purchase Decisions
}

\author{
Shofif Sobaruddin Akbar ${ }^{1}$, Qristin Violinda ${ }^{2}$, Ira Setiawati ${ }^{3}$, Muhammad \\ Rizwan 4 \\ 1,2,3 Universitas PGRI Semarang, Indonesia, \\ ${ }^{4}$ School of Economics and Management, Yangtze University Jingzhou, Hubei, China
}

A R T I C LE I N F O

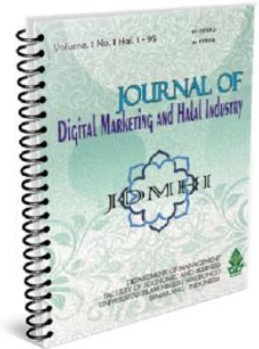

Article history:

Received 9 June 2021

Accepted 22 September 2021

Published 30 October 2021

Keywords:

Product Quality, Product

Design, Brand Image,

Purchasing Decisions
A B S T R A C T

The level of sales of realme smartphones in the low-end and midrange segments is still inferior to other brands. This study aims to identify the influence of consumer purchasing decisions on product quality, product design, and brand image. The population in this study were all realme smartphone consumers. The number of samples in this study was 96 respondents. The sampling technique used was purposive sampling. The analysis tool used is SEM SmartPLS. This study explains that product quality directly influences $40.3 \%$ of purchasing decisions. Product design also directly influences $32.6 \%$ of purchasing decisions, while the brand image does not affect purchasing decisions. Therefore, brand image cannot mediate product quality and design on purchasing decisions. Product design directly affects $41.9 \%$ of brand image, and product quality directly affects $32.2 \%$. Thus, it is necessary to pay attention to these three things to increase sales.

@2021 Journal of Digital Marketing and Halal Industry

\section{Introduction}

With the development of the modern world and globalization today, communication is essential for every community. These needs impact the increasing demand for various types of communication tools, resulting in more competition in the business world in the telecommunications sector. Moreover, the need for communication tools such as cellphones always increases from year to year, especially for types of cellphones with certain brands (Septayuda et al., n.d.).

* Corresponding author.email: qristinviolinda@upgris.ac.id

DOI: http://dx.doi.org/10.21580/jdmhi.2021.3.2.9331 
The development of the telecommunications industry has led to various devices that support the displacement of tablets, PCs, and standard mobile phones with the presence of a new device that facilitates human work, namely smartphones or often known as smartphones (Saraswati \& Rahyuda, 2017).

Currently, people's demand for cellphones is increasing, and this provides a considerable opportunity for cellphone manufacturers to continue to make innovations in the manufacture of cellphones. Starting from a better form, applications and features that are more complete and sophisticated also make people happy and satisfied with the results that have been produced (Septayuda et al., n.d.).

IDC lists the top five most popular brands in Indonesia based on shipments. Namely Vivo, Oppo, Samsung, Xiaomi, and Realme. Vivo is said to hold the largest share in the low-end segment. Vivo relies on distribution to unorganized retail channels for sales in Q2 2020 as these stores are still operating during quarantine. Oppo in the following position reportedly maintains a strong presence in the mid-range category. This category carries a price tag of between USD 200 to USD 400 (ranging from Rp. 2.9 million to Rp. 5.8 million) because its newest models, the A52, A92, and A91, are popular in the market.

While Samsung is said to change its strategy by making the $\mathrm{M}$-series exclusive to the online market in 2Q20, other product lines seem to find it difficult to compete with Chinesebased brands in the midrange to low-end segments. In the following ranking, Xiaomi has benefited from the huge demand for smartphones at affordable prices because the Redmi 8A Pro is popular. Thus, Xiaomi is the share leader in the ultra low-end segment under USD 100 or around Rp. 1.4 million. Finally, Realme, who introduced their new product, Narzo, which is positioned as a gaming phone at an affordable price, is enough to make them survive. However, realme shipments declined for the second quarter in a row.

Realme is the lowest entry-level smartphone brand compared to the Vivo, Oppo, Samsung, and Xiaomi brands. Purchase decisions from the public are a determining factor to increase realme smartphone sales. Purchasing decisions are used as the basis for developing a good product. Therefore, manufacturers need to know the factors that influence purchasing decisions. Kotler and Keller (2008) explain that intelligent companies will fully understand the customer's decision-making process and their experiences in learning, choosing, and using products. Marketers must understand every facet of consumer behavior. Consumer culture has experienced developments that form the basis for shaping the individual community (Saraswati \& Rahyuda, 2017).

Product quality is essential for smartphone manufacturers to improve purchasing decisions. Product quality is the ability of a product or service to fulfill its function, including durability, reliability, accuracy, ease of operation, and improvement of product improvements and other product attributes (Sumarsono \& Santoso, 2019). Based on research (Dewi, 2019), product quality affects purchasing decisions. Based on research (Doni Defriansyah, Islahuddin Daud, 2016), the quality results affect purchasing decisions. Product quality affects purchasing decisions

http://journal.walisongo.ac.id/index.php/JDMHI/index DOI: http://dx.doi.org/10.21580/jdmhi.2021.3.2.9331 
based on research (Saraswati \& Rahyuda, 2017).

Product design can increase differentiation. As a result, the product will positively affect the competitive advantage. Facing this high competition, strategies need to be implemented to handle problems properly. Conditions of intense competition make consumers very vulnerable in making purchasing decisions. Innovations (Sumarsono \& Santoso, 2019). Product design affects purchasing decisions based on research (Simamora \& Kusmiyati, 2017). Research (Sumarsono \& Santoso, 2019) shows that product design results affect purchasing decisions. Based on research (Mukarromah \& Rofiah, 2019), product design results affect purchasing decisions.

A positive brand image has a positive influence on purchasing decisions. The higher the brand image created by the company, the decision-making level to buy also increases (Saraswati \& Rahyuda, 2017). Research (Dewi, 2019) shows that brand image affects purchasing decisions. Based on research (Doni Defriansyah, Islahuddin Daud, 2016), the results obtained that brand image affects purchasing decisions. Based on research (Saraswati \& Rahyuda, 2017), brand image affects purchasing decisions. Therefore, Product Quality, Product Design, Brand Image plays a role in improving Purchase Decisions. Therefore, the study aims to determine Product Quality, Product Design, Brand Image on Realme Smartphone Purchase Decisions.

\section{Literature Review}

\section{Product quality on brand image}

Product quality is the totality of features and characteristics of a product or service based on its ability to satisfy stated or implied needs. Imagery describes the extrinsic nature of products and services, including how the brand tries to meet customers' psychological and social needs (Septayuda et al., n.d. 2019).

Brand image is a picture or impression of a brand that appears in the minds of consumers. Therefore, brand image recommendations owned by consumers will help consumers make purchasing decisions (Saraswati \& Rahyuda, 2017). Moreover, for products that have high quality, consumers will feel the benefits of the quality of the product so that consumers will feel that the products used have a high quality to be able to improve the product's brand image. Therefore, based on research (Saraswati \& Rahyuda, 2017), product quality affects brand image. Therefore, a hypothesis can be drawn as follows:

$\mathrm{H} 1$ : product quality affects brand image

\section{Product design on brand image}

Product design is the totality of features that affect appearance and function in consumer needs. Products resulting from craft product designs generally focus more on the values of uniqueness (uniqueness), beauty (aesthetics), art (art), noble, unique, or distinctive features, and subtlety of taste as essential elements (Sumarsono \& Santoso, 2019). Brand image is a picture or impression of a brand that appears in the minds of consumers (Fataron \& Rohmah, 2019; Kurniawati, 2019; Nurudin, 2020). Consumers' brand image recommendations will help consumers make purchasing decisions (Saraswati \& Rahyuda, 2017).

Consumers interested in a product can not be separated from the first impression of the 
product's design. Therefore, products with attractive designs for consumers, showing the features, uniqueness, and luxury of these products, will attract consumers. So, it will be able to improve the product's brand image.

Based on research (Ciceu Niar, 2019), product design results affect brand image. Therefore, a hypothesis can be drawn as follows:

$\mathrm{H} 2$ : product design affects brand image

\section{Product quality on brand image}

Product quality is the totality of features and characteristics of a product or service based on its ability to satisfy stated or implied needs. Imagery describes the extrinsic nature of products and services, including how the brand tries to meet customers' psychological and social needs (Septayuda et al., n.d. 2019).

Marketing managers must study consumer decision-making to understand how information is obtained, how beliefs are formed, and what products to choose. Therefore, understanding consumers' psychological and personal factors is fundamental and are likely to strongly influence purchasing behavior and brand recall of services, products, and companies (Saraswati \& Rahyuda, 2017).

Product quality is crucial in a consumer purchasing decision process. Consumers in choosing a product also consider the quality of the product. The higher the quality of the product, the better it will attract and improve consumer purchasing decisions. based on research

H3: product quality affects purchasing decisions

\section{Product design on brand image}

Product design is the totality of features that affect the appearance and function in terms of consumer needs. Products resulting from craft product designs generally focus more on the values of uniqueness (uniqueness), beauty (aesthetics), art (art), noble, special or distinctive features, and subtlety of taste as basic elements (Sumarsono \& Santoso, 2019).

Marketing managers must study consumer decision-making to understand how information is obtained, how beliefs are formed, and what products to choose. Therefore, understanding consumers' psychological and personal factors is essential and likely to strongly influence purchasing behavior and brand recall of services, products, and companies (Saraswati \& Rahyuda, 2017).

Product design can increase differentiation. As a result, the product will positively affect the competitive advantage. Facing this high competition, strategies need to be implemented to handle problems properly. Conditions of intense competition make consumers very vulnerable in making purchasing decisions. Innovations (Sumarsono \& Santoso, 2019). Based on research (Simamora \& Kusmiyati, 2017), product design results affect purchasing decisions. Research (Sumarsono \& Santoso, 2019) shows that product design results affect purchasing decisions. Based on research (Mukarromah \& Rofiah, 2019), product design results affect purchasing decisions.

$\mathrm{H} 4$ : product quality affects brand image

\section{Product quality on brand image}

Brand image is a picture or impression of a brand that appears in the minds of consumers. Therefore, brand image 
recommendations owned by consumers will help consumers make purchasing decisions (Saraswati \& Rahyuda, 2017).

Nisel (2001) states that marketing managers must study consumer decision-making well to understand how information is obtained, how beliefs are formed, and what products to choose. Therefore, understanding consumers' psychological and personal factors is very important and is likely to strongly influence purchasing behavior and brand recall of services, products, and companies (Saraswati \& Rahyuda, 2017).

A positive brand image has a positive influence on purchasing decisions. The higher the brand image created by the company, the decision-making level to buy also increases (Saraswati \& Rahyuda, 2017). Based on research (Dewi, 2019) get the results are that brand image affects purchasing decisions. Based on research (Doni Defriansyah, Islahuddin Daud, 2016), the results obtained that brand image affects purchasing decisions. Based on research (Saraswati \& Rahyuda, 2017), brand image affects purchasing decisions.

H5: brand image affects purchasing decisions.

\section{The Method, data, and analysis}

The type of research conducted on the object under study is quantitative research. Namely, the researcher will quantify (number) all the data obtained and then translate it after statistical processing. The reason for choosing this type of research is because all the data obtained are in the form of numbers, and the data can be directly processed easily to test hypotheses. Therefore, quantitative research methods can be interpreted as research methods based on the philosophy of positivism, used to examine specific populations or samples. Data collection using research instruments, data analysis is quantitative/statistical, intending to test established hypotheses (Sugiyono, 2017).

The object of this research is the consumer purchasing decisions of Smartphone Relame in the low-end and mid-range segments in Semarang. The population in this study is unknown, so that in determining the sample using the MoE formula, which gets a total of 96 respondents. Technique sampling using purposive sampling. The criteria in the study used respondents to have a minimum age of 18 years and make a purchase of a realme smartphone at a price of less than Rp. 7 million Rupiah.

Data collection techniques in this study used a questionnaire given to consumers. The data analysis technique used in this study is the Partial Least Square (PLS) approach and uses the SmartPLS 3.0 software. PLS is a variantbased SEM statistical method designed to solve multiple regression when a specific problem occurs in data, for example, a small sample size. Missing data and multicollinearity (Kartini, 2017).

The indicators used to measure the variables in this study are product quality (ease of use, durability, and clarity of function), product design (packaging, colors, characteristics, and models), brand image (consumer perceptions of companies that make goods and services). , consumer perceptions of the users or users of these goods or services including the users themselves, lifestyle and social status, consumer perceptions of the product include attributes, benefits, use and guarantees provided by the product and consumer perceptions of celebrities supporting the advertisement of the product), purchasing 
decisions ( Stability of product information, stability of benefits, product quality and reputation, stability of product purchases and stability of repeat purchases).

Sampling using purposive sampling. The criteria in the study used respondents to have a minimum age of 18 years and make a purchase of a realme smartphone at a price of less than Rp. 7 million Rupiah.

Data collection techniques in this study used a questionnaire given to consumers. The data analysis technique used in this study is the Partial Least Square (PLS) approach and uses the SmartPLS 3.0 software. PLS is a variantbased SEM statistical method designed to solve multiple regression when a specific problem occurs in data, for example, a small sample size. Missing data and multicollinearity (Kartini, 2017).

The indicators used to measure the variables in this study are product quality (ease of use, durability, and clarity of function), product design (packaging, colors, characteristics, and models), brand image (consumer perceptions of companies that make goods and services)., consumer perceptions of the users or users of these goods or services including the users themselves, lifestyle and social status, consumer perceptions of the product include attributes, benefits, use and guarantees provided by the product and consumer perceptions of celebrities supporting the advertisement of the product), purchasing decisions ( Stability of product information, stability of benefits, product quality and reputation, stability of product purchases and stability of repeat purchases).

Measurement Model (Outer Model)

The convergent validity of the measurement model uses a reflection indicator that is assessed based on the relationship between item scores and the score construct, which is calculated using PLS. The Rule of Thumb provides a concurrent validity value. Namely, the Loading factor value must be above 0.7 At the same time, the research is confirmatory, and the Loading factor value ranges from 0.6 to 0.7 for exploratory research is still acceptable. The average variance extracted (AVE) value is above 0,5. But for research in the early stages, the Loading factor value of 0.5-0.6 is considered sufficient (Ghozali, 2015).

\section{Result and Discussion}

\section{Measurement Model (Outer Model)}

The convergent validity of the measurement model uses a reflection indicator that is assessed based on the relationship between item scores and the score construct, which is calculated using PLS. The Rule of Thumb to provide a concurrent validity value, namely the Loading factor value, must be above 0.7. At the same time, the research is confirmatory, and the Loading factor value ranges from 0.6 to 0.7 for exploratory research is still acceptable. The average variance extracted (AVE) value is above 0,5 . But for research in the early stages, the Loading factor value of 0.5-0.6 is considered sufficient (Ghozali, 2015).

Table 1.

Outer loading

\begin{tabular}{lllll}
\hline & $\begin{array}{l}\text { Brand } \\
\text { Image }\end{array}$ & $\begin{array}{l}\text { Product } \\
\text { Design }\end{array}$ & $\begin{array}{l}\text { Purchase } \\
\text { decision }\end{array}$ & $\begin{array}{l}\text { Product } \\
\text { Quality }\end{array}$ \\
\hline $\mathrm{X} 1.1$ & & & & 0.914
\end{tabular}




\begin{tabular}{|c|c|c|c|c|}
\hline X1.2 & & & & 0.891 \\
\hline X1.3 & & & & 0.803 \\
\hline X2.1 & & 0.879 & & \\
\hline X2.2 & & 0.711 & & \\
\hline X2.3 & & 0.753 & & \\
\hline X2.4 & & 0.901 & & \\
\hline Y.1 & & & 0.877 & \\
\hline Y.2 & & & 0.920 & \\
\hline Y.3 & & & 0.762 & \\
\hline Y.4 & & & 0.647 & \\
\hline Z.1 & 0.814 & & & \\
\hline Z.2 & 0.762 & & & \\
\hline Z.3 & 0.767 & & & \\
\hline Z.4 & 0.788 & & & \\
\hline
\end{tabular}

Table 1 shows that each variable indicator has a value of more than 0.7 , which indicates it is feasible to continue, except for the Y.4 indicator, which is still below 0.7 , so it must be deleted in the research model. The outer loading test after removing the Y.4 indicator gets the following results:
Table 2.

Outer Loading Revision

\begin{tabular}{lllll}
\hline & $\begin{array}{c}\text { Brand } \\
\text { Image }\end{array}$ & $\begin{array}{l}\text { Product } \\
\text { Design }\end{array}$ & $\begin{array}{c}\text { Purchase } \\
\text { Decision }\end{array}$ & $\begin{array}{l}\text { Product } \\
\text { Quality }\end{array}$ \\
\hline X1.1 & & & & 0.914 \\
X1.2 & & & & 0.890 \\
X1.3 & & & & 0.805 \\
X2.1 & & 0.881 & & \\
X2.2 & & 0.706 & & \\
X2.3 & & 0.754 & & \\
X2.4 & & 0.903 & & \\
Y.1 & & & 0.921 & \\
Y.2 & & & 0.952 & \\
Y.3 & & & 0.732 & \\
Z.1 & 0.819 & & & \\
Z.2 & 0.757 & & & \\
Z.3 & 0.766 & & & \\
Z.4 & 0.792 & & & \\
\hline
\end{tabular}

The outer loading revision test results found that all indicator items had passed or above 0.7 , so it was feasible to continue research.

\section{Table 3.}

Validity and Realibility

\begin{tabular}{lcccc}
\hline & $\begin{array}{l}\text { Cronbach's } \\
\text { Alpha }\end{array}$ & rho_A & $\begin{array}{l}\text { Composite } \\
\text { Reliability }\end{array}$ & $\begin{array}{l}\text { Average Variance } \\
\text { Extracted (AVE) }\end{array}$ \\
\hline Brand Image & 0.791 & 0.793 & 0.864 & 0.614 \\
Product Design & 0.828 & 0.844 & 0.887 & 0.665 \\
Purchasing Decision & 0.837 & 0.845 & 0.905 & 0.764 \\
Product Quality & 0.839 & 0.844 & 0.904 & 0.758 \\
\hline
\end{tabular}

The results of testing the validity and reliability can be seen in Table 3 , each of which can be said to be valid and reliable variables.

\section{Structural Model (Inner Model)}

The assessment of the structural model with PLS is indicated by the value of R-Squares on each endogenous latent variable, which is the predictive power of the structural model. Can be called the same as the interpretation of the 
regression. Changes in the value of R-Squares are used to explain whether exogenous latent variables have an effect on endogenous variables and whether they have a substantive effect.

\section{Table 4.}

$R$ Square

\begin{tabular}{ccc}
\hline & R Square & R Square Adjusted \\
\hline Brand Image & 0.379 & 0.366 \\
Decision & 0.527 & 0.511 \\
Purchase & & \\
\hline
\end{tabular}

In providing an assessment of the model

\section{Table 4.}

Parsial Hypotesis Test using PLS, it is done by reviewing the results of the R-square on each latent dependent variable. For example, from the table above, $\mathrm{R}$ Square to brand image is 0.379 or $37.9 \%$, and purchasing decisions is 0.527 or $52.7 \%$.

\section{Hypothesis test}

The significance of the parameters that the estimation process has carried out provides information related to the correlation of variables in the research conducted. The subject used in testing the hypothesis is the value of the output result for inner weight.

\begin{tabular}{llllll}
\hline & $\begin{array}{l}\text { Original } \\
\text { Sample } \\
(\mathrm{O})\end{array}$ & $\begin{array}{l}\text { Sample } \\
\text { Mean } \\
(\mathrm{M})\end{array}$ & $\begin{array}{l}\text { Standard } \\
\text { Deviation } \\
(\text { STDEV }\end{array}$ & $\begin{array}{l}\text { T Statistics } \\
(|\mathrm{O} / \mathrm{STDEV}|)\end{array}$ & $\begin{array}{l}\text { P } \\
\text { Values }\end{array}$ \\
\hline Brand image $>$ Purchase Decision & 0.176 & 0.195 & 0.106 & 1.656 & 0.098 \\
Product Design $>$ > Brand Image & 0.419 & 0.431 & 0.090 & 4.672 & 0.000 \\
Product Design $>$ P Purchase Decision & 0.326 & 0.315 & 0.093 & 3.516 & 0.000 \\
Product Quality $>$ > Brand Image & 0.322 & 0.328 & 0.083 & 3.881 & 0.000 \\
Product Quality $>$ > Purchase Decision & 0.403 & 0.396 & 0.095 & 4.227 & 0.000 \\
\hline
\end{tabular}

The test using bootstrapping aims to minimize the problem of discrepancies in the research data. The results of the test using bootstrapping from the PLS analysis are as follows:

Testing Hypothesis 1 (Product Quality on Brand Image).

The results of the first hypothesis test resulted in a coefficient value of 0.322 , which means that there is a positive effect of product quality on brand image. The value of $\mathrm{P}$ Values is 0.000 , which indicates a value below 0.05 . These results mean that product quality has a positive and significant relationship to brand image. This means that Hypothesis 1 is accepted.

Testing Hypothesis 2 (Product Design on Brand Image).

The results of the second hypothesis test produce a coefficient value of 0.419 , which means that there is a positive effect of product design on brand image. The value of $\mathrm{P}$ Values is 0.000 , which indicates a value below 0.05 . These results mean that product design has a positive and significant relationship to brand image. This means that 
Hypothesis 2 is accepted.

Testing Hypothesis 3 (Product Quality on Purchase Decisions).

The results of the third hypothesis test produce a coefficient value of 0.403 , which means that there is a positive effect of product quality on purchasing decisions. The value of $\mathrm{P}$ Values is 0.000 , which indicates a value below 0.05 . These results mean that product quality has a positive and significant relationship to purchasing decisions. This means that Hypothesis 3 is accepted.

Testing Hypothesis 4 (Product Design on Purchase Decisions).

The results of the fourth hypothesis test produce a coefficient value of 0.326 which means that there is a positive effect of product quality on purchasing decisions. The value of $\mathrm{P}$ Values is 0.000 , which indicates a value below 0.05 . These results mean that product quality has a positive and significant relationship to purchasing decisions. This means that Hypothesis 4 is accepted.

Testing Hypothesis 5 (Brand Image on Purchase Decision).

The results of the fifth hypothesis test produce a coefficient value of 0.176 which means that there is no positive influence of brand image on purchasing decisions. The value of $\mathrm{P}$ Values is 0.098 , which indicates a value above 0.05 . These results mean that brand image does not have a positive and significant relationship with purchasing decisions. This means that Hypothesis 5 is rejected.

\section{Indirect Effect}

Table 5.

Indirect Effect

\begin{tabular}{|c|c|c|c|c|c|}
\hline & $\begin{array}{l}\text { Original } \\
\text { Sample } \\
\text { (O) }\end{array}$ & $\begin{array}{l}\text { Sample } \\
\text { Mean } \\
\text { (M) }\end{array}$ & $\begin{array}{l}\text { Standard } \\
\text { Deviation } \\
\text { (STDEV) }\end{array}$ & $\begin{array}{l}\text { T Statistics } \\
(\mid \mathrm{O} / \text { STDEV } \mid)\end{array}$ & $\begin{array}{l}\mathrm{P} \\
\text { Values }\end{array}$ \\
\hline $\begin{array}{l}\text { Product design }>>\text { Brand Image -> } \\
\text { Purchase Decision }\end{array}$ & 0.074 & 0.084 & 0.051 & 1.445 & 0.149 \\
\hline $\begin{array}{l}\text { Product Quality -> Brand Image -> } \\
\text { Purchase Decision }\end{array}$ & 0.057 & 0.066 & 0.044 & 1.291 & 0.197 \\
\hline
\end{tabular}

\section{Discussion}

Product quality affects the brand image and purchasing decisions

The analysis results in this study prove that product quality and brand image have a positive and significant effect on the Realme Smartphone Purchase Decision. Thus, the quality of the products offered by Realme
Smartphones, such as the quality of Smartphones that can last a long time and are not easily damaged, can attract and attract consumers to buy Realme Smartphones. In addition, the completeness factor or the features that exist on the Realme Smartphone. It also makes a unique attraction for consumers to buy a Realme Smartphone, such as the high camera quality from 48MP-108MP, Battery charging speed 0 . 
50\% Per 17 minutes. The processor has a capacity of $720 \mathrm{G}$ and is accompanied by additional facilities such as NFC (Near Field Communication), which can be used to transfer data and make payments.

Furthermore, the Realme Smartphone provides a repair warranty. The more the quality of the Realme Smartphone products is improved, the higher the consumer's decision to buy a Realme Smartphone. Products that have high quality, consumers who use, will feel the benefits of the quality of the product so that consumers will feel that the products used have a high quality to be able to improve the product's brand image. The study results follow the study results (Saraswati \& Rahyuda, 2017), getting the results that product quality affects the brand image and purchasing decisions.

\section{Product design affects the brand image and purchasing decisions}

The analysis results in this study prove that Product Design has a positive and significant effect on purchasing decisions for Realme smartphones. Although the designs on the Realme Smartphone are diverse, the screen already carries a super amoled panel so that the colors displayed are more apparent and more comfortable for the eyes. Chasing and various and colorful features provide special interest in the eyes of consumers. The latest, simple, elegant model, and also provides various types of desired features with varying sizes, has also become an attraction for consumers for Realme Smartphones Public.

This study follows the research results (Simamora \& Kusmiyati, 2017), which states that product design affects image and purchasing decisions. Research results (SUMARSONO \& SANTOSO, 2019) explain that product design affects purchasing decisions and brand image. Furthermore, based on research (Mukarromah \& Rofiah, 2019), product design results affect purchasing decisions.

Thus, it can be described that the more product designs there are on the Realme Smartphone, the more attractive it will be for consumers to buy Realme Smartphones. Product design can increase differentiation. Therefore, the product will positively affect the competitive advantage of the product. According to (Sumarsono \& Santoso, 2019), facing this high competition, strategies need to be carried out to handle problems properly. Conditions of intense competition make consumers very vulnerable in making purchasing decisions.

\section{The brand image does not affect purchasing decisions}

The analysis results show that brand image does not affect purchasing decisions. Through hypothesis testing, it shows an insignificant effect. This is supported by previous research by Wenas (2013), which concluded that brand image has no significant effect on purchasing decisions. The brand image does not affect purchasing decisions due to several factors, namely the product's function to be used, literacy skills or information about the product to be purchased, and the financial ability to buy the product. Under the theory put forward by Kotler (2005), consumer purchasing decisions can be influenced by one's psychological factors, namely motivation, perception, learning, beliefs, and 
attitudes. A person's purchase decision will go through the stages of a purchase decision. These stages, among others, are based on product function, literacy ability, and financial ability.

\section{Conclusion}

This study explains that product quality directly influences $40.3 \%$ of purchasing decisions. Product design also directly influences $32.6 \%$ of purchasing decisions, while the brand image does not affect purchasing decisions. Therefore, brand image cannot mediate product quality and product design on purchasing decisions. Product design directly affects $41.9 \%$ of brand image, and product quality directly affects $32.2 \%$ on brand image. The originality of this study is to offer the concept of product quality, product design, the brand image on Realme Smartphone Purchase decision. Thus, no studies have investigated this causality.

\section{Recommendations}

The company pays better attention to the durability of its products by using better materials than before to increase the perception of better product quality. For sustainable marketing development, producers should research the models desired by consumers. The analysis results in this study prove that Product Design has a positive and significant effect on Realme Smartphone Decisions. Thus, it can be described that the more product designs there are on the Realme Smartphone, the more attractive it will be for consumers to buy Realme Smartphones. In addition to the various designs on the Realme Smartphone, colorful colors and attractive features provide special interest in the eyes of consumers. The latest, simple, elegant models, and various features that vary from the lowest to the highest prices, are an attraction for consumers to buy Realme smartphones.

\section{References}

Dewi, R. N. T. (2019). Pengaruh Kualitas Produk, Citra Merek Dan Celebrity Endorser Terhadap Keputusan Pembelian Smarthphone Melalui Minat Beli Sebagai Variabel Intervening. Ejournal Administrasi Bisnis, 7(4, 2019), 414.

Doni Defriansyah, Islahuddin Daud, W. N. (2016). Pengaruh Citra Merek, Harga Dan Kualitas Produk Terhadap Keputusan Pembelian Smartphone Samsung (Studi Kasus Mahasiswa Universitas Sriwijaya Indralaya) Doni Defriansyah 1 , Islahuddin Daud 2 , \& Welly Nailis 3. 2, 89-102.

Fataron, Z. A., \& Rohmah, H. (2019). Effect Analysis of Trust, Ease, Information Quality, Halal Product on Online Purchase Decision of 2016-2018 Batch Students of Islamic Economics Study Program in UIN Walisongo at Shopee Marketplace. Journal of Digital Marketing and Halal Industry, 1(1), 1-18. https://doi.org/10.21580/jdmhi.2019. 1.1.4772

Ghozali, Imam, 2015, Aplikasi Analisis Multivariate Dengan Program IBM SPSS 23, Universitas Diponegoro, Semarang 
Kartini, 2017, Pengaruh Penerimaan Teknologi, Faktor Sosial, Kondisi Pemfasilitasi Dan Computer SelfEfficacy Terhadap Pemanfaatan EOffice Kantor Imigrasi Di Makassar, Jurnal Analisis, Desember 2017, Vol. 6 No. 2: 180 - 187 Issn 2303-100x

Kotler, Philip. 2005. Manajemen Pemasaran. Jilid 1 dan 2. Jakarta: PT Indeks. Kelompok Gramedia

Kurniawati, L. M. (2019). Effect Of Product Quality And Brand Equity On Buying Interest. Journal of Digital Marketing and Halal Industry, 1(1), 75-82. https://doi.org/10.21580/jdmhi.2019. 1.1.4369

Mukarromah, D. S., \& Rofiah, C. (2019). Pengaruh Citra Merek, Desain Produk Dan Kualitas Produk Terhadap Keputusan Pembelian Sepatu Merek Bata. JMD: Jurnal Riset Manajemen \& Bisnis Dewantara, 2(1), 27-36. https://doi.org/10.26533/jmd.v2i1.34 6

Nurudin, N. (2020). Analysis of the Effect of Visual Merchandising, Store Atmosphere and Sales Promotion on Impulse Buying Behavior. Journal of Digital Marketing and Halal Industry, 2(2), 167. https://doi.org/10.21580/jdmhi.2020. 2.2.6283

Saraswati, A., \& Rahyuda, I. (2017). Brand
Image Memediasi Kualitas Produk Dan Harga Dengan Keputusan Pembelian Smartphone Apple Di Kota Denpasar. E-Jurnal Manajemen Universitas Udayana, 6(6), 255257.

Septayuda, I., Universitas, D., \& Darma, B. (n.d.). Keputusan Pembelian Smartphone Xiaomi-4X. 3, 127-136.

Simamora, V., \& Kusmiyati, E. (2017). Pengaruh Desain Produk Dan Brand Image Terhadap Keputusan Pembelian Pada Teh Botol Sosro Dengan Kualitas Produk Sebagai Variabel Moderating. Jurnal Online Internasional \& Nasional Unversitas 17 Agustus 1945 Jakarta, 20(1), 43-54.

Sumarsono, H., \& Santoso, A. (2019). Pengaruh Citra Merek (Brand Image), Kualitas Produk, Dan Desain Produk Terhadap Keputusan Pembelian Pada Produk Batik Mukti. ISOQUANT: Jurnal Ekonomi, Manajemen Dan Akuntansi, $\quad 3(1)$, 81. https://doi.org/10.24269/iso.v3i1.242

Wenas, J. 2013. Kualitas Produk, Harga, Promosi, dan Kualitas Pelayanan Pengaruhnya terhadap Keputusan Pembelian Spring Bed Comforta. Jurnal EMBA. Volume 1, Nomor 4. Desember 2013.https://ejournal.unsrat.ac.id/in dex.php/emba/article/view/2741. Diakses pada tanggal 3 Maret 2018 